\title{
Pengaruh Pemangkasan Batang Utama dan Cabang Primer terhadap Hasil dan Kualitas Pare (Momordica charantia L.)
}

\section{The effects of Main Stem and Primary Branches Pruning on The Yield and Quality of Bitter Gourd (Momordica charantia L.)}

\author{
Qaanitatul Hakim Ipaulle, Dody Kastono*) \\ Departemen Budidaya Pertanian, Fakultas Pertanian, Universitas Gadjah Mada \\ Jalan Flora No. 1, Bulaksumur, Sleman, Yogyakarta 55281, Indonesia. \\ ${ }^{*}$ Penulis untuk korespondensi Email: dodykastono@gmail.com
}

\begin{abstract}
Bitter gourd is widely used by Indonesian people in the culinary, cosmetic, and herbal medicine fields. The large number of community needs must be balanced with bitter gourd productivity. This study aim to get the interactions between the treatment of the main stem and primary branches pruning to increase the yield and quality of bitter gourd. The study was conducted in February-June 2019 in Kuden, Sitimulyo, Piyungan, Bantul, Yogyakarta. The study was designed by 2 × 5 factorial split plot design with three blocks as replications. The main plot consists of two levels that is pruning and without pruning the primary branches. The sub plot consists of five levels that is without pruning the main stem nodes, pruning leaving 13, 16, 19, and 21 plant nodes. The data were analyzed with analysis of variance. If there were significantly difference among the treatments continued with Honestly Significant Difference test with significantly $95 \%$. The results showed that the interaction between the treatment of the main stem pruning and the primary branches pruning just occurred in the number of primary branches. The treatment of main stem pruning and primary branches pruning in this research carried out in fact actually reduces the number of fruits per plant, the fresh weight of fruit per fruit, so that the weight of fruit per plant also decreases. Even so, the results of the correlation test between the three variables with plant productivity showed a significant positive correlation that was quite to strong.
\end{abstract}

Keywords: bitter gourd, branch, node.

\section{INTISARI}

Pare merupakan jenis tanaman sayur yang banyak dimanfaatkan masyarakat Indonesia di bidang kuliner, kosmetik, hingga obat herbal. Banyaknya kebutuhan masyarakat tersebut harus seimbang dengan produktivitas pare. Salah satu cara untuk meningkatkan produksi dapat dilakukan dengan teknik pemangkasan yang tidak banyak dilakukan oleh petani. Penelitian ini bertujuan untuk mendapatkan interaksi antara perlakuan pemangkasan batang utama dengan cabang primer untuk meningkatkan hasil dan kualitas pare. Penelitian dilaksanakan pada bulan Februari-Juni 2019 di dusun Kuden, Sitimulyo, Piyungan, Bantul, Yogyakarta. Rancangan penelitian disusun dengan rancangan petak terbagi faktorial $2 \times 5$, tiga blok sebagai ulangan. Petak utama terdiri dari dua taraf yaitu pemangkasan dan tanpa pemangkasan cabang primer. Anak petak terdiri dari lima taraf yaitu tanpa pemangkasan batang utama, pemangkasan menyisakan 13, 16, 19, dan 21 ruas. 
Data diuji menggunakan analisis varians, jika terdapat signifikansi diantara perlakuan kemudian dilanjutkan dengan uji Honestly Significant Difference dengan taraf kepercayaan $95 \%$. Hasil penelitian menunjukkan bahwa perlakuan pemangkasan batang utama dan cabang primer memberikan pengaruh nyata pada jumlah cabang primer dengan interaksi antar faktor, namun tidak berbeda nyata terhadap jumlah bunga betina dan bunga jantan per tanaman, rasio bunga betina: jantan, fruit set, jumlah buah per tanaman, bobot segar buah, panjang dan diameter buah. Hal tersebut mengindikasi perlakuan pemangkasan batang utama dan cabang primer yang dilakukan nyatanya malah menurunkan jumlah buah per tanaman, bobot segar buah per buah, sehingga bobot buah per tanaman juga menurun. Meski begitu, hasil uji korelasi antar ketiga variabel tersebut dengan produktivitas tanaman menunjukkan hubungan signifikan korelasi positif yang cukup-sangat kuat.

Kata kunci: pare, pemangkasan, ruas

\section{PENDAHULUAN}

Pare (Momordica charantia L.) merupakan salah satu jenis hortikultura yang dalam bahasa Inggris dikenal sebagai bitter gourd, bitter melon, maupun bitter squash karena berasal dari familia Cucurbitaceae yang memiliki ciri khas rasanya yang pahit. Pare dapat tumbuh baik dan banyak dibudidayakan di daerah tropis dan sub-tropis. Pare memiliki rasa yang pahit, namun di Indonesia, masyarakat telah banyak memanfaatkan pare sebagai sayuran dan obat tradisional. Beberapa penelitian menunjukkan bahwa pare mengandung antioksidan yang membantu menekan respon inflamasi dan menurunkan kadar glukosa darah pada penyakit diabetes (Liao et al. 2012).

Di pasaran harga buah pare berkisar antara Rp. 3.000,- hingga Rp. 5.000,- per kilogram. Bagi para petani modern, maka peluang pasar tersebut sangat menjanjikan. Salah satu cara untuk meningkatkan hasil panen yang banyak dilewatkan petani adalah proses pemangkasan pare. Belum banyak petani yang mengetahui mengenai manfaat dari pemangkasan tanaman pare yang berpotensi untuk meningkatkan hasil panen pare. Menurut Yadi et al. (2012) pemangkasan tanaman ada dua macam, yaitu pemangkasan untuk memilih batang produksi dan pemangkasan pemeliharaan. Pemangkasan produksi perlu dilakukan agar tanaman dapat berproduksi maksimal dengan melakukan pemilihan batang yang dipelihara, sedangkan pemangkasan pemeliharaan dilakukan dengan memangkas bagian tanaman yang tidak berguna. Zulkarnain (2014) menambahkan tindakan pemangkasan juga dilakukan dengan membuang bagianbagian tanaman, seperti cabang atau ranting untuk mendapatkan bentuk tertentu sehingga dicapai tingkat efisiensi yang tinggi di dalam pemanfaatan cahaya matahari, mempermudah pengendalian hama/penyakit, serta mempermudah pemanenan. 
Pemangkasan pada tanaman pare dilakukan selama 2 kali yaitu pada umur 3 dan 6 mst. Cabang-cabang dipotong dan diarahkan agar tunas tumbuh menyebar sehingga produksi buah maksimal. Pada saat 6 mst dilakukan pemangkasan pada cabang tua yang tidak tumbuh lagi. Selain itu, daun yang tua dibuang, begitu juga cabang yang rusak, patah, atau terkena serangan penyakit (Susila, 2006).

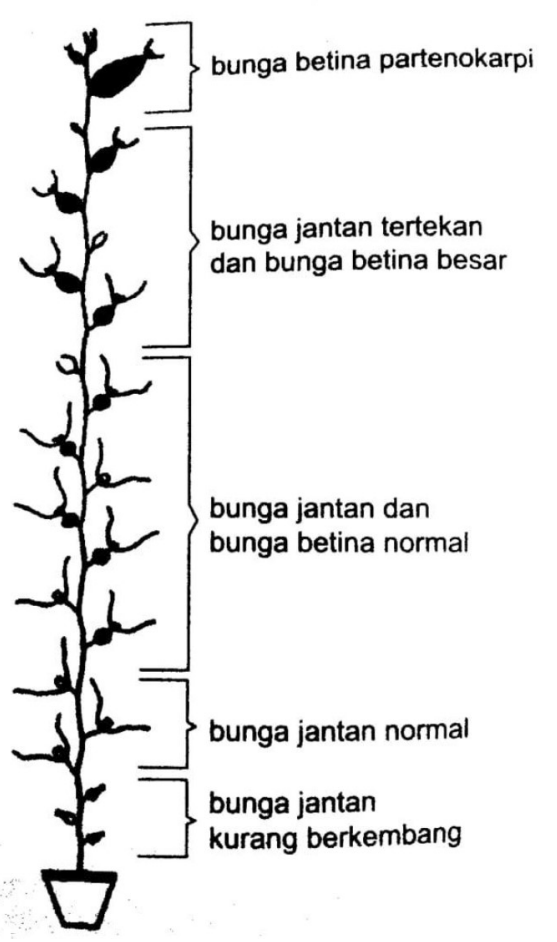

Gambar 1. Urutan perkembangan bunga jantan dan bunga betina yang normal pada tanaman timun (Cucumis sativus) (Sumber: Zulkarnain, 2014).

Pentingnya pemangkasan cabang primer adalah untuk mengurangi pertumbuhan cabang lateral yang terlalu banyak dan tidak produktif. Palada dan Chang (2003) mengatakan bahwa tanaman pare (labu pahit) mengembangkan banyak cabang lateral (samping) yang tidak produktif. Untuk meningkatkan hasil, 4-6 cabang lateral dipertahankan. Pemangkasan batang utama juga penting untuk mematahkan dominasi apikal, sehingga tunas lateral terpilih dapat tumbuh lebih baik, lebih panjang, meningkatkan jumlah bunga betina dan jumlah buah terbentuk. Zulkarnain (2014) menambahkan ekspresi kelamin (sex expression) pada familia Cucurbitaceae (timun, semangka, melon, dan labu), dimana urutan keluarnya bunga yang normal pertama kali adalah bunga jantan (staminate) saja, diikuti bunga betina (pistilate) secara berselang seling dengan bunga jantan, dan akhirnya hanya bunga betina saja yang dibentuk (Gambar 1). 
Menurut Kusumayati et al. (2015) yang menyatakan bahwa tanaman memiliki banyak hormon di antaranya yaitu hormon giberelin dan auksin yang berfungsi dalam pemanjangan dan pembesaran sel pada tumbuhan. Badrudin et al. (2015) menyatakan bahwa jumlah auksin yang berlebihan pada tanaman akan mengakibatkan terjadinya dormansi pucuk yang menghambat pertumbuhan tunas di bawahnya. Dormansi pucuk juga akan menyebabkan tunas bunga terhambat untuk tumbuh. Dengan demikian, pemangkasan batang utama diharapkan membuat tanaman akan lebih cepat berbunga.

Beberapa penelitian tentang pemangkasan tanaman familia Cucurbitaceae di antaranya yaitu hasil penelitian Yadi et al. (2012) menunjukkan bahwa pemangkasan pada tanaman mentimun memberikan pengaruh sangat nyata terhadap panjang buah, bobot buah, dan produksi dengan rata-rata tertinggi diperoleh pada perlakuan pemangkasan dua daun dan dua cabang pada ruas 6-12 secara berturut-turut yaitu sebesar $22.29 \mathrm{~cm}, 396.67 \mathrm{~g} / \operatorname{tanaman}$, dan 49.98 ton.ha-1. Hasil penelitian Zamzami et al. (2015) juga menunjukkan bahwa secara kuantitas, kombinasi 1 tanaman mentimun per polibag dan pemangkasan dengan menyisakan 12 ruas menghasilkan bobot buah yang lebih tinggi daripada perlakuan pemangkasan dengan menyisakan 8, 10, dan 14 ruas. Selanjutnya, hasil penelitian Gustianty (2016) menyatakan bahwa perlakuan pemangkasan pada ruas keenam dan memelihara 1-3 daun sangat berpengaruh nyata pada diameter batang tanaman umur 6 mst dan terhadap produksi per tanaman mentimun. Penelitian pada tanaman pare masih sangat jarang dikaji khususnya pada perlakuan pemangkasan. Penelitian ini dilakukan dengan tujuan membuktikan bahwa perlakuan pemangkasan ruas batang utama dan pemangkasan cabang primer pada tanaman pare Broco F1 akan memberikan pengaruh terhadap hasil dan kualitas pare. Hasil dan kriteria kualitas pare dilihat dari keadaan fisik pare yaitu ukuran dan bobot buah pare yang sesuai dengan standar deskripsi varietas yang laku di pasaran.

\section{BAHAN DAN METODE}

Penelitian dilaksanakan mulai Februari hingga Juni 2019 bertempat di dusun Kuden, desa Sitimulyo, kecamatan Piyungan, kabupaten Bantul, provinsi Yogyakarta. Pengamatan laboratorium dilaksanakan di Laboratorium Manajemen dan Produksi Tanaman, Sub Laboratorium Ekologi Tanaman, Departemen Budidaya Pertanian, Universitas Gadjah Mada, Yogyakarta. Bahan tanam yang digunakan dalam penelitian ini adalah benih pare Broco F1 yang didapatkan dari toko pertanian. Pare hibrida broco F1 memiliki sifat mampu beradaptasi di dataran rendah sampai dengan menengah, buah 
yang dihasilkan berwarna hijau, rasa agak pahit, daging buah tebal, diameter buah 5.5 $\mathrm{cm}$, panjang buah $20 \mathrm{~cm}$, dan toleran terhadap penyakit kresek.

Bahan yang digunakan sebagai media tanam dalam polybag yaitu tanah sawah dan pupuk kandang sapi yang telah matang (2:1), pupuk NPK 5 g/polybag, pestisida berbahan aktif sipermetrin $30 \mathrm{gL}^{-1}$, Alkohol $70 \%$ sebagai disinfektan alat pemangkasan. Benih pare disemai pada plastik semai yang berisi media tanam tanah dan sekam (2:1). Pada masing-masing plastik semai diisikan 2 benih pare, kemudian diletakkan di tempat yang teduh. Pada tahap persemaian, penyiraman dilakukan satu kali per hari. Media tanam tanah dan pupuk kandang (2:1) dicampurkan terlebih dahulu kemudian dimasukkan ke dalam polybag dengan ukuran $35 \mathrm{~cm}$ x $35 \mathrm{~cm}$. Satu minggu setelah semai, bibit dipindah tanam ke dalam polybag. Pemupukan susulan dengan pupuk NPK dilakukan interval 7 hari sekali sebanyak 5 g/tanaman hingga 11 mst dengan cara di tugal (saat hujan) dan kocor (tidak hujan). Lanjaran dibuat setelah tanaman berumur 3 minggu setelah tanam yaitu saat tanaman sudah memunculkan sulurnya. Pada penelitian ini, perlakuan pemangkasan ruas batang utama dengan menyisakan 13 dan 16 ruas dilakukan pada saat tanaman berumur 24 hari setelah tanam (hst). Sedangkan, pemangkasan ruas batang utama dengan menyisakan 19 dan 21 ruas dilakukan pada saat tanaman berumur 32 hst. Perlakuan pemangkasan cabang primer dilakukan bersamaan yaitu pada saat tanaman berumur 28 dan 42 hst. Pemangkasan cabang primer dilakukan sebanyak dua kali bertujuan untuk mempertahankan jumlah cabang primer yang sama pada tanaman sampai masa panen akhir yaitu 12 minggu setelah tanam (mst). Pemangkasan cabang primer secara selektif dengan memilih cabangcabang primer (Gambar 2.) yang sudah memiliki bakal bunga betina yaitu tiga cabang teratas dari pangkasan ruas batang utama. Jumlah cabang primer ini dipertahankan tetap 3 sampai tanaman berumur 12 mst. 


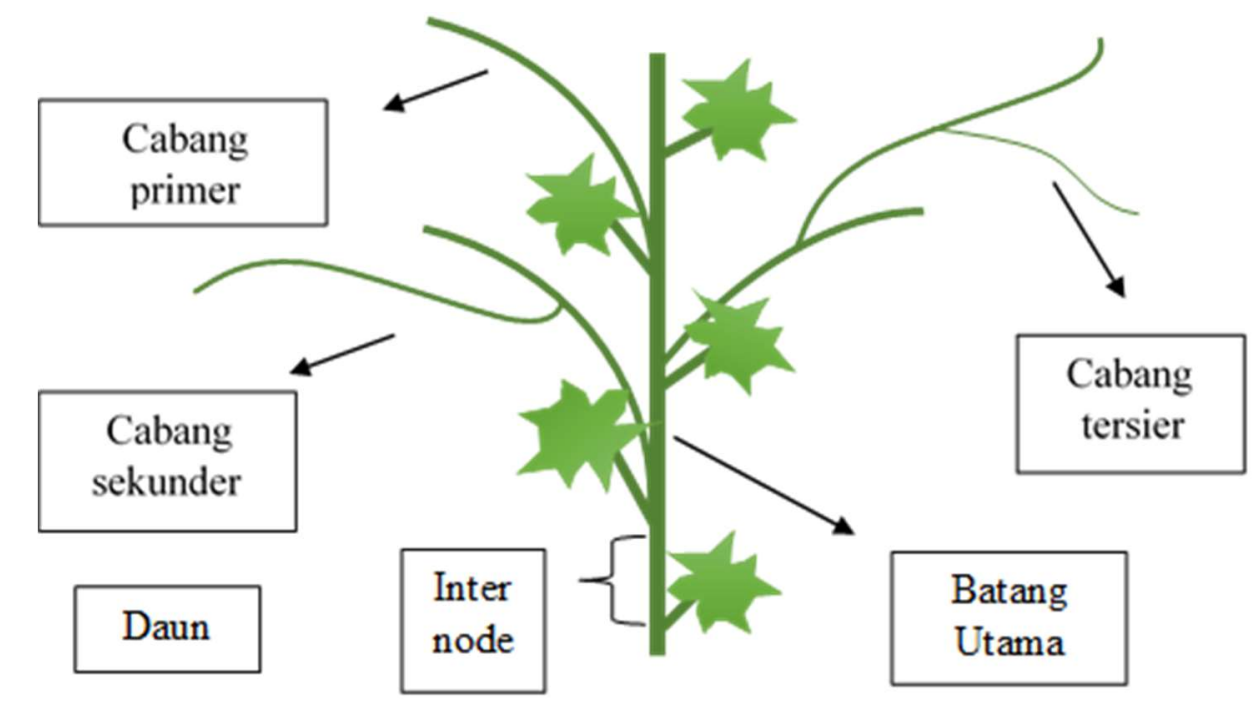

Gambar 2. Sketsa pembentukan cabang pada tanaman pare (Momordia charantia L.) (sumber: dokumentasi pribadi, 2019).

Pemangkasan dilakukan dengan gunting, bagian gunting dan batang/cabang yang akan dipangkas sebelumnya disemprot dengan desinfektan. Dalam satu petak perlakuan terdapat 10 tanaman, 2 tanaman akan diambil untuk setiap pengamatan sampel distruktif saat tanaman berumur 4, 8, dan 12 mst. Diameter batang dan buah diukur menggunakan jangka sorong digital, keadaan iklim mikro diukur menggunakan lux meter (intensitas cahaya), dan termohigrometer (suhu dan kelembaban). Bobot segar dan bobot kering tanaman sampel ditimbang dengan timbangan digital, luas daun diukur menggunakan WinDIAS leaf area meter, dan bobot kering didapatkan setelah tanaman sampel di oven. Rancangan penelitian disusun dengan Rancangan Petak Terbagi Faktorial 2 × 5 dengan tiga blok sebagai ulangan. Faktor utama terdiri dari dua taraf yaitu pemangkasan dan tanpa pemangkasan cabang primer. Anak petak terdiri dari lima taraf yaitu: tanpa pemangkasan ruas batang utama, pemangkasan menyisakan 13, 16, 19, dan 21 ruas tanaman. Tanaman sampel destruktif diambil sebanyak tiga kali yaitu saat tanaman berumur 4, 8, dan 12 mst. Data yang diperoleh dianalisis secara statistika dengan uji analisis varians (ANOVA) pada taraf $\alpha=5 \%$. Apabila data berbeda nyata maka dilanjutkan dengan uji Honestly Significant Difference $(\alpha=0,05)$. Analisis data dikerjakan menggunakan perangkat lunak R Studio 3.6.0.

\section{HASIL DAN PEMBAHASAN}

Tanaman pare merupakan tanaman yang tumbuh merambat. Batang utama yang dibiarkan tumbuh merambat menyebabkan pertumbuhan ruas yang tak terbatas selama pertumbuhan tanaman masih berlangsung sepanjang masa tanam. Ruas ini merupakan tempat tumbuhnya daun sekaligus tempat cabang-cabang primer tumbuh 
dari ketiak daun. Cabang sekunder adalah cabang yang tumbuh pada cabang primer, sedangkan cabang tersier adalah cabang yang tumbuh pada cabang sekunder, begitu seterusnya (Gambar 2.).

Tabel 1. Rerata jumlah cabang primer tanaman pare umur 12 mst pada perlakuan pemangkasan batang utama dan cabang primer.

\begin{tabular}{|c|c|c|}
\hline \multirow{2}{*}{ Perlakuan } & \multicolumn{2}{|c|}{ Jumlah Cabang Primer } \\
\hline & Pangkas cabang primer & Tanpa pangkas cabang \\
\hline \multicolumn{3}{|l|}{ Pangkasan batang utama } \\
\hline Tanpa pangkas ruas & $3,00 \mathrm{~b}$ & 21,33 a \\
\hline Menyisakan 13 ruas & $3,00 \mathrm{~b}$ & $8,67 \mathrm{~b}$ \\
\hline Menyisakan 16 ruas & $3,00 \mathrm{~b}$ & $8,17 \mathrm{~b}$ \\
\hline Menyisakan 19 ruas & $3,00 \mathrm{~b}$ & $8,67 \mathrm{~b}$ \\
\hline Menyisakan 21 ruas & $3,00 \mathrm{~b}$ & $9,00 \mathrm{~b}$ \\
\hline Interaksi antar perlakuan & \multicolumn{2}{|c|}{$(+)$} \\
\hline Koefisien Keragaman (\%) & \multicolumn{2}{|c|}{8,29} \\
\hline $\begin{array}{ll}\text { Keterangan: } & \text { angka yang c } \\
& \text { terdapat per } \\
& \text { Difference (al } \\
& \text { perlakuan. }\end{array}$ & \multicolumn{2}{|c|}{$\begin{array}{l}\text { angka yang diikuti huruf yang berbeda pada satu kolom yang sama menunjuka } \\
\text { terdapat perbedaan signifikan menurut uji lanjut Tukey Honestly Significar } \\
\text { Difference (alpha } 0,05), \text { mst }=\text { minggu setelah tanam, }(+)=\text { terdapat interaksi anta } \\
\text { perlakuan. }\end{array}$} \\
\hline
\end{tabular}

Dari hasil penelitian pada Tabel 1. menunjukkan bahwa tanaman pare yang tanpa pangkas batang utama dan cabang primer menghasilkan rerata jumlah cabang primer tertinggi yaitu sebanyak 21 cabang. Hal tersebut terjadi karena tanaman yang tanpa pangkas batang utama akan memiliki arah pertumbuhan vegetatif ke atas yang terus menerus selama masa hidupnya. Tempat tumbuh cabang lateral yang tersedia lebih banyak yaitu pada ruas-ruas batang utama, sehingga jumlah cabang primernya lebih banyak dibandingkan dengan interaksi perlakuan lainnya. Namun, jumlah cabang primer yang banyak tersebut tidak terlalu panjang, sehingga mengurangi tempat tumbuh bunga betina. Hal tersebut dapat menyebabkan menurunnya jumlah buah yang terbentuk sehingga menurunkan hasil. Dalam penelitian Irawati dan Setiari (2009) juga menunjukkan hal yang sama bahwa tanaman yang tidak diberi perlakuan pemangkasan, memiliki panjang tunas lateral yang paling rendah. Hal ini terjadi karena adanya dominasi apikal, sehingga pertumbuhan dipusatkan pada tunas apikal. Sedangkan pada tanaman dipangkas, panjang tunas lateralnya melebihi tanaman kontrol karena terjadi pematahan dominasi apikal akibat pemangkasan pucuk. 
Tabel 2. Rerata jumlah bunga jantan per tanaman, jumlah bunga betina per tanaman, dan rasio bunga jantan:betina, dan fruit set selama $12 \mathrm{mst}$ pada perlakuan pemangkasan batang utama dan cabang primer.

\begin{tabular}{|c|c|c|c|c|}
\hline Perlakuan & $\begin{array}{l}\text { Jumlah bunga } \\
\text { jantan per } \\
\text { tanaman }\end{array}$ & $\begin{array}{c}\text { Jumlah } \\
\text { bunga } \\
\text { betina per } \\
\text { tanaman }\end{array}$ & $\begin{array}{l}\text { Rasio } \\
\text { bunga } \\
\text { betina: } \\
\text { jantan }\end{array}$ & $\begin{array}{c}\text { Fruit set } \\
\text { (\%) }\end{array}$ \\
\hline \multicolumn{5}{|c|}{ Pemangkasan batang utama } \\
\hline Tanpa pangkas ruas & 325,50 a & $4,71 \mathrm{a}$ & $1: 73$ a & 56,36 a \\
\hline Menyisakan 13 ruas & 322,75 a & 5,63 a & $1: 64$ a & 47,76 a \\
\hline Menyisakan 16 ruas & 293,58 a & $5,00 \mathrm{a}$ & $1: 60 \mathrm{a}$ & $51,10 \mathrm{a}$ \\
\hline Menyisakan 19 ruas & $275,25 a$ & $6,17 \mathrm{a}$ & $1: 59 a$ & 34,16 a \\
\hline Menyisakan 21 ruas & $331,04 \mathrm{a}$ & $6,79 \mathrm{a}$ & $1: 47 \mathrm{a}$ & $39,82 \mathrm{a}$ \\
\hline \multicolumn{5}{|c|}{ Pemangkasan cabang primer } \\
\hline Pangkas cabang primer & $270,15 p$ & $5,45 p$ & $1: 55 p$ & $47,38 p$ \\
\hline Tanpa pangkas cabang & $349,10 p$ & $5,87 p$ & $1: 66 p$ & $44,29 p$ \\
\hline Interaksi antar perlakuan & $(-)$ & $(-)$ & $(-)$ & $(-)$ \\
\hline Koefisien Keragaman (\%) & 10,51 & 16,41 & 18,12 & 18,35 \\
\hline
\end{tabular}

Hasil penelitian pada Tabel 2. menunjukkan bahwa pemberian perlakuan pemangkasan batang utama dan pemangkasan cabang primer tidak memberikan pengaruh yang nyata terhadap jumlah bunga jantan per tanaman dan jumlah bunga betina per tanaman, rasio bunga betina:jantan, Fruit set, dan tidak terjadi interaksi antara perlakuan pemangkasan batang utama dengan pemangkasan cabang primer.

Pada tanaman merambat, umumnya populasi bunga jantan memang akan lebih dominan daripada bunga betina. Pemangkasan cabang primer bagian pangkal batang seharusnya dapat menekan pertumbuhan bunga jantan dan menaikkan pertumbuhan bunga betina (Gambar 1.). Pemangkasan batang utama juga diharapkan mampu memperpanjang pertumbuhan cabang lateral yang dipertahankan sehingga tempat tumbuh tunas bunga betina juga akan lebih banyak, karena bunga betina jarang sekali tumbuh pada ruas batang utama. Hal ini sependapat dengan Palada dan Chang (2003) yang menyatakan bahwa dengan melakukan pemangkasan cabang lateral bagian bawah (pangkal) akan meningkatkan jumlah bunga per tanaman dengan meningkatkan jumlah bunga di cabang lateral bagian atas.

Namun, pada penelitian hal tersebut tidak terjadi. Hal ini dikarenakan ledakan hama Epilachna sp. yang menyerang area pertanaman penelitian. Tingkat kerusakan tanaman akibat serangan hama diperkirakan sebesar $30 \%$. Daun yang rusak akibat serangan menyebabkan terjadinya persaingan organ tanaman untuk menggunakan asimilat yang dihasilkan tanaman yaitu antara mengganti organ vegetatif yang rusak, pertumbuhan organ generatif, dan proses pengisian buah. Dengan persaingan tersebut, bunga betina akan semakin tertekan di atas pertumbuhan bunga jantan yang umumya 
tumbuh lebih dominan pada tanaman merambat. Proporsi jumlah bunga betina dengan jantan akan menurun, sehingga menurunkan jumlah buah yang dihasilkan dalam satu tanaman (Fruit set). Hal tersebut didukung oleh Ahmed et al. (2004) dalam Wijaya et al. (2018) bahwa perbedaan rasio bunga jantan dan bunga betina dalam satu tanaman akan mempengaruhi jumlah buah pertanaman pada berbagai kondisi lingkungan.

Tabel 3. Rerata jumlah buah per tanaman, bobot segar buah per tanaman $(\mathrm{g})$, dan bobot kering buah per tanaman $(\mathrm{g})$ selama 12 mst pada perlakuan pemangkasan batang utama dan cabang primer.

\begin{tabular}{|c|c|c|c|c|c|}
\hline \multirow{2}{*}{ Perlakuan } & \multicolumn{3}{|c|}{ Jumlah buah } & \multirow{2}{*}{$\begin{array}{l}\text { Bobot } \\
\text { segar buah } \\
\text { per buah } \\
\text { (g) }\end{array}$} & \multirow{2}{*}{$\begin{array}{c}\text { Bobot segar } \\
\text { buah per } \\
\text { tanaman }(\mathrm{g})\end{array}$} \\
\hline & SKP & TKP & Total & & \\
\hline
\end{tabular}

\begin{tabular}{lccccc}
\hline Pangkas batang utama & & & & & \\
Tanpa pangkas ruas & $2,59 \mathrm{a}$ & $0,50 \mathrm{a}$ & $3,09 \mathrm{a}$ & $39,88 \mathrm{a}$ & $104,31 \mathrm{a}$ \\
menyisakan 13 ruas & $2,55 \mathrm{a}$ & $1,37 \mathrm{a}$ & $3,93 \mathrm{a}$ & $46,96 \mathrm{a}$ & $118,48 \mathrm{a}$ \\
menyisakan 16 ruas & $2,28 \mathrm{a}$ & $0,79 \mathrm{a}$ & $3,08 \mathrm{a}$ & $43,30 \mathrm{a}$ & $97,98 \mathrm{a}$ \\
menyisakan 19 ruas & $2,10 \mathrm{a}$ & $0,87 \mathrm{a}$ & $2,97 \mathrm{a}$ & $43,81 \mathrm{a}$ & $92,09 \mathrm{a}$ \\
menyisakan 21 ruas & $2,51 \mathrm{a}$ & $0,62 \mathrm{a}$ & $3,14 \mathrm{a}$ & $50,64 \mathrm{a}$ & $129,34 \mathrm{a}$ \\
\hline Pangkas cabang primer & & & & & \\
Pangkas cabang primer & $2,42 \mathrm{p}$ & $0,71 \mathrm{p}$ & $3,14 \mathrm{p}$ & $45,95 \mathrm{p}$ & $109,62 \mathrm{p}$ \\
Tanpa pangkas cabang & $2,39 \mathrm{p}$ & $0,95 \mathrm{p}$ & $3,34 \mathrm{p}$ & $43,88 \mathrm{p}$ & $107,26 \mathrm{p}$ \\
\hline Interaksi antar perlakuan & $(-)$ & $(-)$ & $(-)$ & $(-)$ & $(-)$ \\
\hline Koefisien Keragaman (\%) & 16,64 & 15,35 & 18,12 & 18,77 & 12,45
\end{tabular}

Keterangan: angka yang diikuti huruf yang sama pada satu kolom yang sama menunjukan tidak terdapat perbedaan signifikan menurut uji lanjut Tukey Honestly Significant Difference (alpha 0,05), SKP = Standar Kelayakan Panen, TKP = Tidak masuk Kelayakan Panen, $\mathrm{mst}=$ minggu setelah tanam, $(-)=$ tidak ada interaksi.

Hasil penelitian pada Tabel 3. menunjukkan bahwa perlakuan pemangkasan batang utama dan pemangkasan cabang primer tidak memberikan pengaruh yang berbeda nyata pada jumlah buah yang tidak layak panen (TKP) dengan jumlah buah yang masuk dalam standar kelayakan panen (SKP), sehingga jumlah buah total yang terbentuk juga tidak berbeda nyata. Buah yang belum memenuhi standar kelayakan panen adalah buah yang terbentuk pada tahap awal sebagai tanda berhasilnya penyerbukan, namun belum layak untuk dipasarkan. Hal ini menurut Ashari (1998) dalam Susanto et al. (2019) yang mengatakan bahwa fruit set berdasarkan tahap perkembangan terbagi dua yaitu awal (initial fruit set) dan akhir (final fruit set). Tahap awal mulai terjadi saat pembengkakan/ pertumbuhan ovari, sedangkan tahap akhir adalah jumlah buah yang masih menempel pada tanaman sampai matang fisiologis. Tahap awal biasanya sangat tinggi persentase buah yang terbentuk, dapat berkisar 
antara 50-100 \% keberhasilan penyerbukan dan menghasilkan pembesaran ovari. Pada tahap akhir yaitu persentase buah yang terbentuk dapat berkurang, dengan beberapa kondisi faktor eksternal yang mempengaruhi, seperti bakal buah yang pembesaran ukurannya stagnan, berubah warna menjadi kuning, mengkerut dan akhirnya rontok.

Perlakuan pemangkasan batang utama dan cabang primer juga tidak memberikan pengaruh yang berbeda nyata terhadap bobot segar buah per buah dan bobot segar buah per tanaman (Tabel 3.). Pare Broco F1 dengan deskripsi varietas potensi panjang buah adalah $20 \mathrm{~cm}$ dengan diameter $5,5 \mathrm{~cm}$ namun, tidak diketahui bobot buah segar per buah dan hasil per tanaman. Menurut Palada dan Chang (2003) pemilihan varietas tergantung pada preferensi pasar di wilayah tertentu, terkandang juga didasarkan pada warna dan bentuk buah. Secara umum, ada tiga jenis: 1) kecil, panjang $10-20 \mathrm{~cm}, 100-300 \mathrm{~g}$, biasanya gelap hijau, sangat pahit; 2) panjang, 30-60 cm, 200$600 \mathrm{~g}$, berwarna hijau muda dengan tonjolan ukuran sedang, dan hanya sedikit pahit; dan 3) berbentuk kerucut, panjang 9-12 cm, 300-600 g, hijau terang ke gelap dengan alur menonjol, rasa cukup pahit hingga sangat pahit. Dari pendapat tersebut dapat diambil garis lurus bahwa dengan panjang buah $20 \mathrm{~cm}$, maka buah yang laku di pasar yaitu berbobot segar $100-300 \mathrm{~g}$.
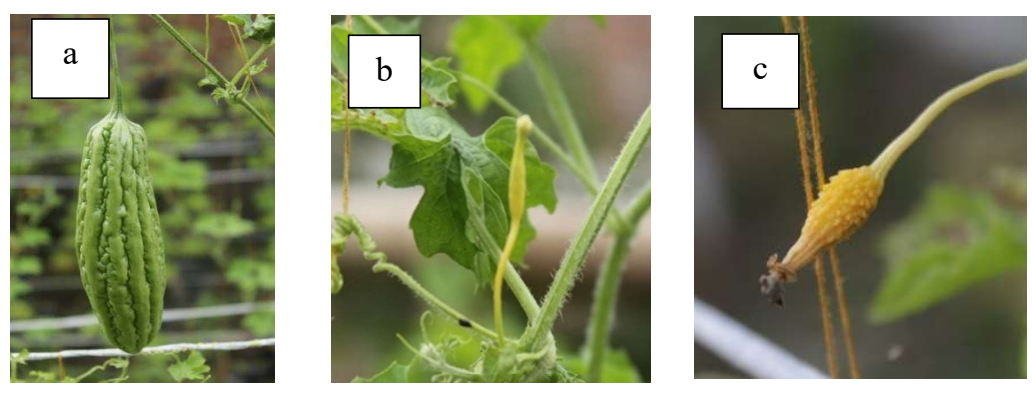

Gambar 3. (a) Buah pare layak panen, (b) dan (c) Buah pare tidak layak panen (sumber: dokumentasi pribadi, 2019).

Pada penelitian ini, buah yang dihasilkan kurang dari potensinya. Bobot segar buah per tanaman yang rendah disebabkan karena bobot segar buah per buah dan jumlah buah yang rendah. Jumlah buah yang rendah dipengaruhi oleh persaingan asimilat antar organ tanaman, bunga dan buah muda yang rontok, serta buah yang tidak berkembang kemudian menguning dan gugur (Gambar 3b dan 3c). 
Tabel 4. Rerata panjang buah dan diameter buah pare selama 12 mst pada perlakuan pemangkasan batang utama dan cabang primer.

\begin{tabular}{lcc}
\multicolumn{1}{c}{ Perlakuan } & Panjang buah $(\mathrm{cm})$ & $\begin{array}{c}\text { Diameter buah } \\
(\mathrm{cm})\end{array}$ \\
\hline Pemangkasan batang utama & & \\
Tanpa pangkas ruas & $11,66 \mathrm{a}$ & $2,94 \mathrm{a}$ \\
Pangkas menyisakan 13 ruas & $13,55 \mathrm{a}$ & $3,34 \mathrm{a}$ \\
Pangkas menyisakan 16 ruas & $12,02 \mathrm{a}$ & $3,15 \mathrm{a}$ \\
Pangkas menyisakan 19 ruas & $12,11 \mathrm{a}$ & $3,38 \mathrm{a}$ \\
Pangkas menyisakan 21 ruas & $15,85 \mathrm{a}$ & $3,79 \mathrm{a}$ \\
\hline Pemangkasan cabang primer & & $3,46 \mathrm{p}$ \\
Pangkas cabang primer & $13,34 \mathrm{p}$ & $(-)$ \\
Tanpa pangkas cabang & $12,73 \mathrm{p}$ & 11,60 \\
\hline Interaksi antar perlakuan & $(-)$ & 20,36 \\
\hline Koefisien Keragaman (\%) & angka yang dikuti huruf yang sama pada satu kolom yang sama menunjukan tidak \\
\hline Keterangan: & Difference (alpha 0,05), mst = minggu setelah tanam, $(-)=$ tidak ada interaksi.
\end{tabular}

Dari hasil penelitian pada Tabel 4. menunjukkan bahwa perlakuan pemangkasan batang utama dan cabang primer tidak memberikan pengaruh yang berbeda nyata terhadap kualitas fisik buah yaitu panjang dan diameter buah yang dihasilkan. Bahan tanam pare Broco F1 memiliki deskripsi varietas dengan potensi panjang buah $20 \mathrm{~cm}$, berdiameter $5,5 \mathrm{~cm}$. Pada hasil penelitian ini panjang dan diameter buah masih jauh dari potensinya. Tujuan utama dari praktek pemangkasan adalah mendapatkan keseimbangan yang tepat antara jumlah buah dan ukuran buah dengan peningkatan manajemen pencahayaan (Sarani et al. 2015). Menurut Cahyono (2003) dalam Harpitaningrum et al. (2017) mengatakan bahwa ukuran buah yang dihasilkan dipengaruhi oleh sifat genetik dari kultivar yang ditanam, kesesuaian lingkungan tempat tumbuh, jumlah buah yang dihasilkan setiap tanaman, maupun perlakuan waktu pemanenan. Namun faktor genetik tanaman lebih dominan dalam menghasilkan diameter buah dibandingkan dengan faktor lingkungan. Pada penelitian ini faktor serangan hama berpengaruh sangat besar dalam pertumbuhan tanaman pare. Pengaruh perlakuan pemangkasan baik pemangkasan batang utama maupun cabang primer menjadi bias karena tanaman harus mengganti organ vegetatif yang rusak dimasa pertumbuhan organ generatif setelah proses pemangkasan dilakukan. Hal ini mengakibatkan perang asimilasi antara pertumbuhan vegetatif dan organ generatif, sehingga buah yang terbentuk akan mengalami penurunan bentuk dan bobot. 
Tabel 5. Korelasi variabel pengamatan dengan produktivitas tanaman

\begin{tabular}{ll}
\hline \multicolumn{1}{c}{ Variabel Pengamatan } & Produktivitas \\
\hline Jumlah Cabang Primer & $-0,17^{\text {tn }}$ \\
Jumlah Bunga Betina & $0,39^{*}$ \\
Jumlah Bunga Jantan & $-0,27^{\text {tn }}$ \\
Rasio Betina:Jantan & $-0,27^{\text {tn }}$ \\
Jumlah Buah Layak Panen & $0,76^{*}$ \\
Jumlah Buah Tidak Layak Panen & $-0,19^{\text {tn }}$ \\
Fruit set & $-0,24^{\text {tn }}$ \\
Bobot Segar Buah per Buah & $0,76^{*}$ \\
Bobot Segar Buah per Tanaman & $1,00^{*}$ \\
Panjang Buah & $0,5^{*}$ \\
Diameter Buah & $0,29^{\text {tn }}$ \\
\hline
\end{tabular}

Keterangan:

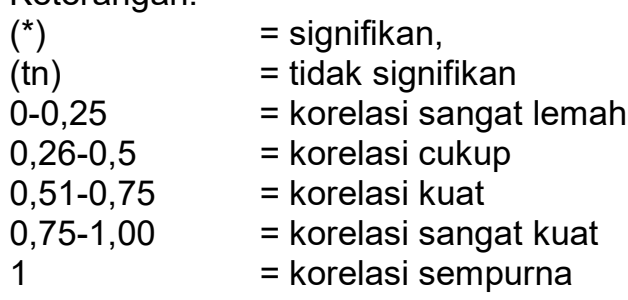

Hasil uji korelasi pada Tabel 5. menunjukkan bahwa variabel jumlah bunga betina dan panjang buah berkorelasi cukup terhadap produktivitas tanaman, variabel jumlah buah layak panen dan bobot segar buah per buah berkorelasi sangat kuat terhadap produktivitas tanaman, sedangkan variabel pengamatan bobot segar buah per tanaman berkorelasi sempurna terhadap produktivitas tanaman. Hal tersebut membuktikan bahwa sebenarnya perlakuan pemangkasan batang utama dan cabang primer yang diberikan memang berpotensi meningkatkan hasil dan kualitas hasil tanaman karena hubungan korelasi yang positif.

\section{KESIMPULAN}

Interaksi antara perlakuan pemangkasan batang utama dengan cabang primer terjadi pada variabel jumlah cabang primer. Kombinasi tanaman yang tidak dipangkas batang utama dan cabang primernya memiliki jumlah cabang primer yang lebih banyak. Namun, jumlah cabang primer yang banyak tersebut tidak terlalu panjang, sehingga mengurangi tempat tumbuh bunga betina. Hal tersebut dapat menyebabkan menurunnya jumlah buah yang terbentuk sehingga menurunkan hasil. Kombinasi perlakuan lainnya dengan jumlah cabang primer yang lebih rendah juga tidak menaikkan hasil karena persaingan asimilat antara organ vegetatif dan generatif akibat serangan 
hama setelah perlakuan pemangkasan dilakukan. Hal ini mengindikasi bahwa perlakuan pemangkasan yang dilakukan nyatanya malah menurunkan jumlah buah per tanaman, bobot segar buah per buah, sehingga produksi buah per tanaman juga menurun. Meski begitu, hasil uji korelasi antara ketiga variabel tersebut dengan produktivitas tanaman menunjukkan hubungan signifikan korelasi positif yang cukup-sangat kuat.

\section{DAFTAR PUSTAKA}

Badrudin, U., S. Jazilah, dan A. Setiawan. 2015. Upaya peningkatan produksi mentimun (Cucumis sativus $\mathrm{L}$ ) melalui waktu pemangkasan pucuk dan pemberian pupuk posfat. Pena Jurnal IImu Pengetahuan dan Teknologi 20(1): 18-28.

Gustianty, L. R. 2016. Respon pertumbuhan dan produksi tanaman mentimun (Cucumis sativus L.) terhadap pupuk seprint dan pemangkasan. Bernas 12(2): 55-64.

Harpitaningrum, P., dan Sungkawa, I. 2017. Pengaruh konsentrasi paclobutrazol terhadap pertumbuhan dan hasil tanaman mentimun (Cucumis sativus I.) kultivar venus. Agrijati Jurnal IImiah IImu-IImu Pertanian 25(1): 1-17.

Irawati, H., dan Setiari, N. 2009. Pertumbuhan tunas lateral tanaman nilam (Pogostemon cablin Benth) setelah dilakukan pemangkasan pucuk pada ruas yang berbeda. Anatomi Fisiologi 17(2): 11-21.

Kusumayati, N., Nurlaelih, E. E., dan Setyobudi, L. 2015. Tingkat keberhasilan pembentukan buah tiga varietas tanaman tomat (Lycopersicon esculentum Mill.) pada lingkungan yang berbeda. Jurnal Produksi Tanaman 3(8): $683-688$.

Liao, P.C., Tsai, C.C., Chou, C.H., dan Chiang, Y.C. 2012. Introgression between cultivars and wild populations of Momordica charantia L. (Cucurbitaceae) in Taiwan. International journal of molecular sciences 13(5): 6469-6491.

Palada, M. C., dan Chang, L. C. 2003. Suggested cultural practices for bitter gourd. AVRDC International Cooperators' Guide, 03-54.

Sarani, M., Mehraban, A., Ganjali, H. R., dan Khemmari, E. 2015. Effect of pruning and row distance on some characteristics in Karela. International Journal of Biosciences 6(1): 1-8.

Susanto, A., Sri H., dan M, Burhan R. 2019. Pengaruh pemberian boron dan waktu pemanenan polen terhadap peningkatan produksi dan viabilitas polen tetua jantan semangka (Citrullus lanatus Thunberg). Jurnal Bioindustri 1(2): 203-212.

Susila, A.D. 2006. Panduan Budidaya Tanaman Sayuran. Departemen Agronomi dan Hortikultura. Fakultas Pertanian IPB, Bogor.

Wijaya, H.N., Ansoruddin, H., dan Lanna R.G. 2018 Pengaruh waktu penyerbukan dan proporsi bunga betina dengan bunga jantan terhadap hasil dan kualitas benih mentimun (Cucumis sativus L.) hibrida. Bernas 14(1): 85-98. 
Ipaulle dan Kastono / Vegetalika. 2020. 9(3): 474-487

Yadi, S., Karimuna, L., dan Sabaruddin, L. 2012. Pengaruh pemangkasan dan pemberian pupuk organik terhadap produksi tanaman mentimun (Cucumis sativus L.). Jurnal Penelitian Agronomi 1(2): 107-114.

Zamzami, K., Nawawi, M., dan Aini, N. 2015. Pengaruh jumlah tanaman per polibag dan pemangkasan terhadap pertumbuhan dan hasil tanaman mentimun kyuri (Cucumis sativus L.). Jurnal Produksi Tanaman 3(2): 113-119.

Zulkarnain. 2014. Dasar-dasar Hortikultura. Bumi Aksara, Jakarta. 